International Journal of Agriculture, Environment and Bioresearch

Vol. 07, No. 01; 2022

ISSN: $2456-8643$

\title{
GREEN SYNTHESIS OF NANOSILVER PARTICLES FROM PLANTS EXTRACT
}

\author{
Abdul Mueez ${ }^{1}$, Shabbir Hussain ${ }^{2}$, Muhammad Ahmad ${ }^{3}$, Aoun Raza ${ }^{1}$, Iffat Ahmed ${ }^{4}$, Muhammad Amjad ${ }^{* 1}$ \\ ${ }^{1}$ Department of Chemistry, Lahore Garrison University, Lahore-Pakistan \\ ${ }^{2}$ Department of Chemistry, Khwaja Fareed University of Engineering and Information Technology, Rahim Yar \\ Khan-Pakistan \\ ${ }^{3}$ Department of Chemistry, DSNT, University of Education, Lahore-Pakistan \\ ${ }^{4}$ Department of Pharmaceutical Sciences, Superior University Lahore-Pakistan
}

https://doi.org/10.35410/IJAEB.2022.5703

\begin{abstract}
Metal nanoparticles are getting important day by day in various disciplines like in the field of electronics, catalysts, and the field of magnets, mechanics, bio-medical, medicinal cosmetic, bioimaging, materials for fuel cell and photovoltaic cell and in high-speed modern age communication increasing on a regular basis. It is all because of their distinct characteristic physical, biological and chemical properties, which are increasing their popularity every day. This review shows the instant biological synthesis of nanosilver particles by utilizing extracts from different parts the plant such as leaves, roots, flowers, bark and seeds. This review is aimed to provide information about the new innovation regarding synthesis of nanosilver particles through plant mediation and characterization techniques concerned. The cytotoxicity of smaller nanoparticles is greater as compared to the larger ones. In the end, this review concludes with the application of nanosilver particles in various fields and their future. Future prospective and biohazards of nano metals are additionally mentioned.
\end{abstract}

Keywords: Nanoparticles; Silver nanoparticles; Biosynthesis; Characterization; Applications.

\section{INTRODUCTION}

Nanoparticles find an important research area in today's science [1-3] due to their broad range of applications in biological [4-7] and nonbiological [8-11] fields. Biosynthesis is defined as the synthesis of Nano-sized particles from biological sources such as microorganisms and plants [12]. Because they are eco-friendly, as these sources are free from hazards linked with other modes of nanoparticle synthesis [13]. Green chemistry principles actually increase safety parameters and improve their efficiency and therefore reduces their toxic influence on society and the environment. Environment-friendly synthesis of nanoparticles (NPs) by biological means encompasses three major areas i.e., eco-friendly usage of solvent, utilization of green reducing agent to reduce ions, and utilization of the substances with no toxicity which performs as stabilizing agents in the synthesis [14]. Biosynthesis of nanosilver particles by the use of plant extracts from various sources has been reported by researchers $[15,16]$. During the synthesis of nanoparticles, the extracts of plants work as reducing agents, these extracts of plants contain various kinds of enzymes, vitamins, amino acids, polysaccharides, proteins, polyphenols, etc., which work as reducing agents [17]. For a long, metal silver has been widely used in different biomedical-related products. Silver nanoparticles have gained prominence over other available nanoparticles because of their exciting optical, electromagnetic, catalytic properties and plasmonic activity, and some bactericidal and bacteriostatic effects as well as their 
antiproliferative actions. Their wide applications in various fields such as photography, catalysis, optics, mirrors, electronics, dentistry clothing and in the foodstuff related packaging industry have increased their own worth in the present market [18].

Noble silver metal has kept its extraordinary dimensional properties in optical and electronic even by going to quantum size which laid its foundation in the field of nanotechnology [19, 20]. Nanoparticle actually means a particulate matter of size 1-100nm [21]. By having a size of nanometers its very advantageous for getting a large surface area to volume ratio for its maximum use [22]. Nanoparticles in solution by having large surface area upon their conformation and their distribution results in their exciting and unique physical and chemical features which are of great use in fields such as antimicrobial development [23], bio-molecular detection, diagnostics [24], micro-electronics components [25] reactional catalysis [26], sensing devices and drugs for cancerous cells [27].

A notable increase in the eco-friendly synthesis of nanosilver particles has made it a major contributor in the field of nanotechnology in which extracts from different parts of plants, fungi and microorganisms are used for the synthesis of nanoparticles as an alternative to conventional physical and chemical modes [28]. Keeping in view the imporance of nanoparticles [29-33], current studies were performed to review the eco-friendly synthesis of nanosilver particles that have many advantages over conventional methods.

\section{Why choose biological synthesis of silver nano particles rather than physical and chemical synthesis?}

Methods of biological synthesis have many advantages which include cost- effectiveness, simple and environment friendly. Synthesis of nanoparticles using biological methods by means of micro-organisms [34], biocatalysts [35] and extracts of a plant from its various parts offer a lot of advantages over conventional (chemical and physical) modes of nanoparticle synthesis [36-38].

Due to unfavorable reaction parameters and the intense toxicity of the chemicals by using conventional ways of stable nanoparticles production face challenges of nanoparticle aggregation. Therefore, modern methods which are based on the principle of green chemistry have shown the minimum toxic effects for stable nanoparticle synthesis [39, 40]. Mostly, the conventional method is employed to arrange the nanoparticles of metal. Additionally, the use of chemicals in physical and chemical synthesis modes are typically costly and hazardous while the biogenic ways are inexpensive and shows environmental friendly method for biological synthesis of nanosilver particles from various microorganisms (fungi, yeast and bacterium, etc.) and different parts of the plant such as stem, root, latex, leaves, flower, peel, fruits. Many phytochemicals like polysaccharides, proteins, amino acids, saponins, carboxylic acids, polyphenols, enzymes and amino polyose obtained from plants acting as reducing and capping agents during the synthesis of nanoparticles are mostly employed. The agro-waste and micro-organisms materials are the only cost-effective way for the synthesis of nanoparticles, necessary to minimize the utilization of the harmful chemicals and inspires "green synthesis" of synthesizing nanoparticles practice [41, 42].

This technique is very simple, easy, less energy and time-consuming as compared to other techniques such as physical and chemical methods. Biological methods for the synthesis of nanoparticles have many advantages in terms of resources, time requirement, availability of massive materials, high density, stability and solubility in water [43]. Biogenic synthesis of metal 
nanoparticles provide many opportunities for the consumption of unpreserved waste materials. The use of eco-friendly and economical technologies is increasing day by day has shown a guide to biological synthesis techniques [44]. The chemical synthesis method for the synthesis of nanoparticles produces toxic substances that are absorbed on the surface and cause some serious health diseases. The chemically synthesized nanomaterials have limited applications in the various field of medica [45]. It has been observed that three modes are usually used for the synthesis of silver nanoparticles: plant extracts, fungi and bacteria. The bottom-up technique is used for the biosynthesis of silver nanoparticles in which oxidation and reduction reactions take place. The microbial enzymes or phytochemicals have reducing or antioxidant properties that act on the particular compounds and provide desired nanoparticles. In the synthesis of nanoparticles by biological method mostly three components are involved such as reducing agent, solvent and stabilizing agent. It is necessary during the synthesis of silver nanoparticles that the reducing agents should be environmental-friendly and stabilizing should also be non-toxic. In a brief, it is concluded that the synthesis of silver nanoparticles through biological methods have several advantages ges like fast synthesis, more yields, low cost and environmnet-friendly [46, 47]. Hence, the synthesis of nanoparticles from plant extract is an alternative method for the production of nanoparticles on large scale commercially.

\section{Reason Behind Choosing the Plant Mediated Biosynthesis of Silver Nano Particles}

Synthesis of nanoparticles by biological means has gotten superiority by eliminating the complex and time-taking procedures of maintaining cell culture for synthesis [48]. Plant extracts use are very advantageous as they are safe, non-toxic and easily available in our environment and also they are much faster than the microbes in nanoparticle synthesis as they contain numerous metabolites that help in reducing Ag ions. Phytochemicals present in plants are mainly involved in the reduction of silver ions. Flavones, amides, ketones, terpenoids, carboxylic acids and aldehydes are the main phytochemicals involved in the reduction of $\mathrm{Ag}$ ions. Moreover, watersoluble phytochemicals i.e., quinones, flavones and organic acids are involved in the quick reduction of $\mathrm{Ag}$ ion. Researchers have found that plants of the type $\mathrm{x}$ erophytes have biomolecules like anthraquinone and emodin which tautomerizes to form nanoparticles of $\mathrm{Ag}$. While in the mesophytes three kinds of benzoquinones namely remirin, cyperquinone and dietchequinone are found as phytochemicals involved in the reduction. After illustrating all the above studies it is proposed that in the synthesis of Nanosilver particles phytochemicals are directly involved in their reduction [49].

Plant parts, including fruit [50] leaf [51], bark [52], seed [53], peel [54] and root [55] extracts work very well in the biosynthesis of $\mathrm{Ag}$ nanopariticles under moderate experimental conditions and replacing hazardous and toxic chemicals by polyphenols, proteins, flavonoids, sugar or saponins or as reducing agents as well as capping agents. Plant mediated green synthesis of Ag nanoparticles is shown in Fig.1 


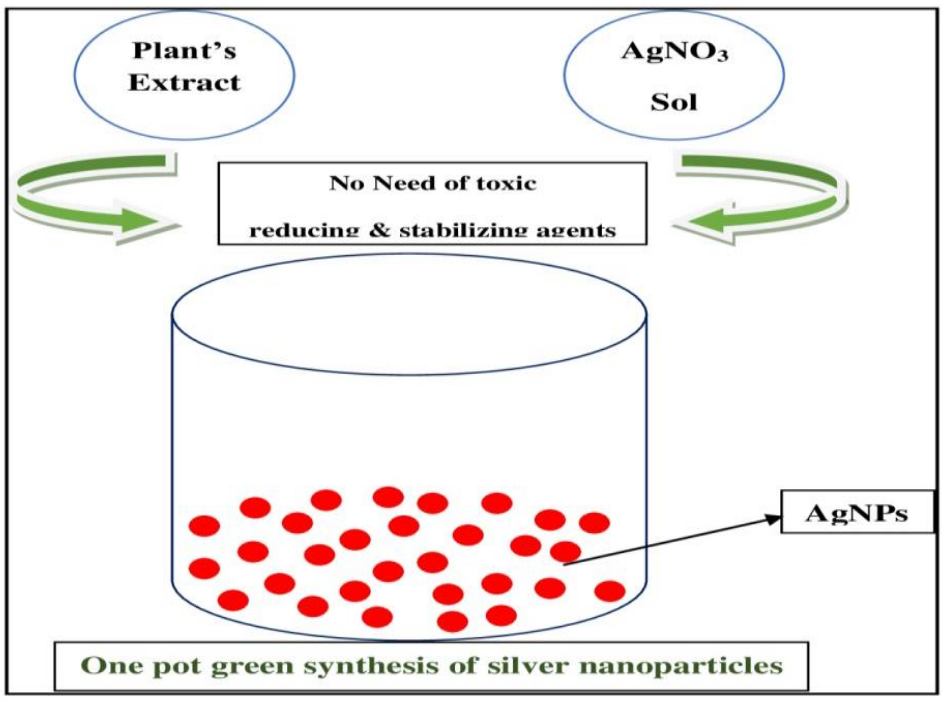

Fig.1: Biosynthesis of Ag nanoparticles by using plant extract

Nanosilver of various sizes have been developed by using plant extracts of Tectona grandis (30$40 \mathrm{~nm}$ ) [56], Myrmecodia pendans (10-20 nm) [57], and Syzygium cumini (10-15 nm) [58]. Moreover, there are great number of plants has been reported for the synthesis of Nan silver particles few of them are given in Table 1.

Table 1: Plant mediated green synthesis of silver (Ag) nanoparticles

\begin{tabular}{|c|c|c|c|}
\hline $\begin{array}{c}\text { Serial } \\
\text { No. }\end{array}$ & Plants Botanical Name & $\begin{array}{c}\text { Nanopaticles size } \\
(\mathbf{n m})\end{array}$ & $\begin{array}{c}\text { References for the } \\
\text { given plant }\end{array}$ \\
\hline 1. & Abutilon indicum & 106 & {$[59]$} \\
\hline 2. & Achyranthus aspera L. & $20-30$ & {$[60]$} \\
\hline 3. & Acorus calamus & 19 & {$[61]$} \\
\hline 4. & Aerva lanata & 18.62 & {$[62]$} \\
\hline 5. & Allium cepa & 33.6 & {$[63]$} \\
\hline 6. & Allium sativum L. & $4.4 \pm 1.5$ & {$[64]$} \\
\hline 7. & Aloe vera & $15.2 \pm 4.2$ & {$[65]$} \\
\hline
\end{tabular}


Vol. 07, No. 01;2022

ISSN: $2456-8643$

\begin{tabular}{|c|c|c|c|}
\hline 8. & Alstonia scholaris & 50 & [66] \\
\hline 9. & Andrographis paniculata Nees. & 28 & [67] \\
\hline 10. & Annona muricata & $20-53$ & [68] \\
\hline 11. & Aristolochia indica & $30-55$ & [69] \\
\hline 12. & Artocarpus heterophyllus & 10.78 & [70] \\
\hline 13. & Asiatic Pennywort & $18-21$ & [71] \\
\hline 14. & Astragalus gummifer Labill & $13.1 \pm 1.0$ & [72] \\
\hline 15. & Averrhoa carambola & 14 & [73] \\
\hline 16. & Azadirachta indica & 50 & [74] \\
\hline 17. & Calliandra haematocephala & 70 & [75] \\
\hline 18. & Calotropis gigantea & $5-30$ & [76] \\
\hline 19. & Calotropis procera & 12.33 & [77] \\
\hline 20. & Capsicum annuит $\mathrm{L}$. & $30-70$ & [78] \\
\hline 21. & Carica papaya & $60-80$ & [79] \\
\hline 22. & Chenopodium album $\mathrm{L}$. & 12 & [80] \\
\hline 23. & Cinnamomum camphora & $10-20$ & [81] \\
\hline 24. & Cinnamon zeylanicum & $50-100$ & [82] \\
\hline 25. & Citrullus colocynthis $\mathrm{L}$. & 31 & [83] \\
\hline 26. & Citrus limon & $10-30$ & [84] \\
\hline 27. & Clerodendrum serratum & $5-30$ & [85] \\
\hline 28. & Cocos nucifera & 22 & [86] \\
\hline 29. & Coleus aromaticus Lour. & $40-50$ & [87] \\
\hline 30. & Coriandrum sativum & 26 & [88] \\
\hline 31. & Crataegus douglasii & 29.28 & [18] \\
\hline 32. & Cucumis sativus & $8-10$ & [89] \\
\hline 33. & Cucurbita maxima & 19 & [61] \\
\hline 34. & Datura metel L. & $16-40$ & [90] \\
\hline 35. & Desmodium triflorum (L) DC. & $5-20$ & [91] \\
\hline 36. & Dioscorea bulbifera L. & $8-20$ & [92] \\
\hline 37. & Dioscorea oppositifolia $\mathrm{L}$. & 14 & [93] \\
\hline 38. & Emblica officinalis & $10-70$ & [38] \\
\hline 39. & Enteromorpha flexuosa & $2-32$ & [94] \\
\hline 40. & Eucalyptus chapmaniana & 60 & [95] \\
\hline 41. & Eucalyptus globulus & $1.9-4.3$ and $5-25$ & [96] \\
\hline
\end{tabular}


Vol. 07, No. 01;2022

ISSN: $2456-8643$

\begin{tabular}{|c|c|c|c|}
\hline 42. & Euphorbia helioscopia & $2-14$ & [97] \\
\hline 43. & Euphorbia hirta & 31 & [98] \\
\hline 44. & Excoecaria agallocha & 20 & [99] \\
\hline 45. & Ficus carica & 21 & [100] \\
\hline 46. & Glycyrrhiza Glabra L. & 20 & [101] \\
\hline 47. & Grewia flaviscences & $50-70$ & [102] \\
\hline 48. & Helicteres isora & $30-40$ & [103] \\
\hline 49. & Hemidesmus indicus & 25.24 & [104] \\
\hline 50. & Hibiscus cannabinus $\mathrm{L}$. & 9 & [105] \\
\hline 51. & Hibiscusrosa sinensis & 14 & [106] \\
\hline 52. & Holarrhena antidysenterica & $2-70$ & [107] \\
\hline 53. & Hydrastis canadensis & 111 & [108] \\
\hline 54. & Hydrilla verticilata (L.f.) Royle. & 65.55 & [109] \\
\hline 55. & Hypnea musciformis & $40-65$ & [110] \\
\hline 56. & Jatropha curcas & $10-20$ & [111] \\
\hline 57. & Justicia adhatoda & $5-50$ & [112] \\
\hline 58. & Lantana camara L. & 12.55 & [113] \\
\hline 59. & Leonuri herba $\mathrm{L}$. & $9.9-13.0$ & [114] \\
\hline 60. & Lycopersicon esculentum & $10-40$ & [115] \\
\hline 61. & Medicago sativa & $2-20$ & [116] \\
\hline 62. & Mentha piperita $\mathrm{L}$. & 90 & [117] \\
\hline 63. & Momordica cymbalaria & 15.5 & [118] \\
\hline 64. & Morinda citrifolia & $30-55$ & [119] \\
\hline 65. & Morinda pubescens L. & $25-50$ & [120] \\
\hline 66. & Morinda tinctoria & $79-96$ & [121] \\
\hline 67. & Moringa oleifera & 11 & {$[61]$} \\
\hline 68. & Mukia maderaspatana & $13-34$ & [122] \\
\hline 69. & Musa balbisiana & 50 & [123] \\
\hline 70. & Myristica fragrans & $7-20$ & [124] \\
\hline 71. & Myrmecodia pendan & $10-20$ & {$[57]$} \\
\hline 72. & Nelumbo nucifera & 16.7 & [125] \\
\hline 73. & Nerium indicum & 29 & {$[98]$} \\
\hline 74. & Ocimum sanctum $\mathrm{L}$. & 10 & [126] \\
\hline
\end{tabular}


Vol. 07, No. 01;2022

ISSN: $2456-8643$

\begin{tabular}{|c|c|c|c|}
\hline 75. & Ocimum tenuiflorum & 50 & [123] \\
\hline 76. & Onosma dichroantha & $5-65$ & [127] \\
\hline 77. & Paederia foetida $\mathrm{L}$. & $4-15$ & [128] \\
\hline 78. & Parthenium hysterophorus L. & 10 & [129] \\
\hline 79. & Pedilanthus tithymaloides (L) Poit. & $15-30$ & [130] \\
\hline 80. & Phyllanthus niruri & $30-60$ & [131] \\
\hline 81. & Phytolacca decandra & 90.87 & [108] \\
\hline 82. & Piper betle L. & 3-37 & [132] \\
\hline 83. & Piper longum & 46 & [133] \\
\hline 84. & Piper pedicellatum & $5-40$ & [134] \\
\hline 85. & Plectranthus barbatus & 20 & [135] \\
\hline 86. & Plukenetia volubilis & $4-25$ & {$[51]$} \\
\hline 87. & Plumeria rubra L. & $32-220$ & [136] \\
\hline 88. & Pongam pinnata L. Pierre & 38 & [137] \\
\hline 89. & Potentilla fulgens & $10-15$ & [138] \\
\hline 90. & Prosopis farcta & 10.8 & [139] \\
\hline 91. & Psidium guajava & $26 \pm 5$ & [140] \\
\hline 92. & Psidium guajava $\mathrm{L}$. & $2-10$ & [141] \\
\hline 93. & Quercus brantii & 6 & [142] \\
\hline 94. & Rheum palmatum & $121 \pm 2$ & [143] \\
\hline 95. & Rosmarinus officinalis & $10-33$ & [144] \\
\hline 96. & Saraca indica & 23 & [145] \\
\hline 97. & Saururus chinensis & 38 & [146] \\
\hline 98. & Sesuvium portulacastrum $\mathrm{L}$. & $5-20$ & [147] \\
\hline 99. & Sinapis arvensis & 14 & [148] \\
\hline 100. & Solanum trilobatum & $12.50-41.90$ & [149] \\
\hline 101. & Solanum xanthocarpum L. & 10 & [150] \\
\hline 102. & Syzygium cumini $\mathrm{L}$ & 93 & [151] \\
\hline 103. & Tagetes erecta & $10-90$ & [152] \\
\hline 104. & Tephrosia tinctoria & 73 & [153] \\
\hline 105. & Terminalia arjuna & $2-100$ & [154] \\
\hline 106. & Thuja occidentalis & 122 & [108] \\
\hline 107. & Trianthema decandra $\mathrm{L}$. & $10-50$ & [155] \\
\hline
\end{tabular}


Vol. 07, No. 01; 2022

ISSN: $2456-8643$

\begin{tabular}{|l|c|c|c|}
\hline 108. & Turbinaria ornata (Turner) & $20-32$ & {$[156]$} \\
\hline 109. & Viburnum lantana & $20-80$ & {$[157]$} \\
\hline 110. & Vitex negundo & $\geq 20$ & {$[158]$} \\
\hline 111. & Zingiber officinale Rosc. & 10 & {$[159]$} \\
\hline 112. & Ziziphus Jujuba & $20-30$ & {$[160]$} \\
\hline
\end{tabular}

Reasons to prefer silver nano particles over the other available nanoparticles

The nanoparticles of metals show their physicochemical properties that are entirely different from the bulk compartment [161]. The metal nanoparticles have distinct properties and are mostly used in medical devices, optics, electronics, medication, medical imaging, environment refinement, renewable energies, catalysis, inks and cosmetics [6, 162-166]. Moreover, silver nanoparticles show a wide range of germicidal behavior [167] and used in different fields, such as medical, electrical, food and health, etc. The utilization of metal nanoparticles became remarkably helpful for the broad selection of client commodities, as well as soaps, textiles, food, pastes, and plastics, to boost their market price [168-170].

The Ag-NPs gained remarkable appreciation because of their salient features like antimicrobial, antisepsis activity they are widely used in medicinal applications and to maintain hygiene conditions [171].

The silver nanoparticles possess distinctive physical, chemical and biological properties that are extensively used and considered as most useful as compared to other noble metals due to their physicochemical properties [15] are very small loss of optical frequency in surface-plasmon propagation [172], high electrical, stability and chemically non-toxic as compared to gold and platinum metals that have high- primitive behaviour, high absorption in visible and IR region, surface-enhanced Raman scattering, high catalytic behaviour, chemical stability and nonlinear optical character. In addition, they possess a wide range of antimicrobial activity against microorganisms. Due to the unique properties of silver nanoparticles, many scientists and technologists have a keen interest to develop nano silver-based antiseptic and disinfectant commodities [173].

Among all metal nanoparticles characterized and developed so far, silver nanoparticles have a noteworthy value to their natural properties of showing antimicrobial activity even in their solidstate. Although the importance of silver was known much earlier, it was not well oppressed except for its use in coins and oriental medicine. It has been expected that almost 320 tons of silver nanoparticles are synthesized every year and also used in food products, nonmedical imaging and biosensing [167, 174].

\section{Characterization tools for analysis of silver nanoparticles}

\section{UV-visible spectrophotometry}

In UV- visible spectra of nanosilver particles, which shows the free movement of electrons as the conduction band and valence band reside very close to each other. Simultaneous oscillation of nanosilver particle electrons in resonance with the incident light causes the surface plasmon resonance (SPR) in it [175-177]. Dielectric medium, shape, morphology, chemical surroundings and size are required for the synthesized nanosilver particles absorption spectra [178-180]. It has 
been shown in many studies nanoparticles of silver ranging from 2 to $100 \mathrm{~nm}$ show the band of absorption at 200 to $800 \mathrm{~nm}$ spectral wavelength in UV- visible region.

\section{X-ray diffraction analysis (XRD)}

The nanosilver particle's crystalline nature is determined by XRD spectra which shows the particles overall oxidation state as the function of time [181].

\section{Scanning electron microscope (SEM)}

Scanning electron microscopy (SEM) is useful in determining the particles of different morphological dimensions of nanoparticles which are synthesized ranging from $10^{-6}$ to $10^{-9}$ meters, all because of its surface imaging technology [182-184]. Scanning electron microscopy (SEM) uses an electron beam of high energy which scans the surface of nanosilver particles and the observation of backscattered electrons gives us the characteristic information about the sample of particles [185].

\section{Transmission electron microscope (TEM)}

The transmission electron microscopy (TEM) technique is pretty helpful in quantifying and detecting the electronic structure and chemical structure of each and every nanoparticle. TEM shows little superiority over the SEM: because it gives high spatial resolution and also gives some more characteristics dimensions about the nanoparticles [186].

\section{Fourier transforms infrared spectroscopy (FTIR)}

Synthesis of metal nanoparticles from bio-molecules involved and their surface chemistry is investigated by Fourier transform infrared (FTIR) spectroscopy [187].

\section{Applications}

Nanoparticles of silver are greatly used in the vast technology of nanoparticles. Many of them are used in byproducts for consumers, i.e., water filtration and system of sanitization, soaps, room sprays, socks, deodorants, and food preservation, which ultimately increases the trade sector of nanosilver particles 2[28, 174, 188, 189]. Nanosilver particles and their derivatives show great catalysis activity for the reduction of dye and its removal [190].

Silver NPs have been studied by many scientists who researched their incorporation in most of the substances in order to obtain more advanced characteristics like in solar cells in which NPs of $\mathrm{Ag}$ act as plasmonic for trapping of light. So, these unique characteristics are enough to make them useful in many other applications i.e., as a catalyst, components in microelectronics, inks, imaging techniques, health -related products, waste management and medical products [191, 192]. Nanoparticle's actions against different fungi promoted them and become a useful product for various fields of consumer and medical products, including medicine, pastes, soap manufacturing, cosmetics, plastics materials, food stuff, highly sensitive surface-enhanced Raman spectroscopy (SERS) technique application [193-195], textiles and water treatment, etc., that have increased their trade value [196]. Additionally, the nanofibres due to their large surface area found very effective in trapping and attracting small particles. This makes nanofibres useful in filtration as a perfect material [197]. Additionally, nanosilver particles account for quite $23 \%$ of obtainable nano-products of the total products in the market. It includes participation from different disciplines of life, i.e., $10.44 \%$ cleaning, $52.61 \%$ health and fitness, $10.04 \%$ food, 
$2.01 \%$ toys, $4.02 \%$ medicine, $3.21 \%$ electronic machines, $6.02 \%$ household equipments, and $11.65 \%$ others [198].

Dong and his co-researchers illustrated that nanosilver particles of various dimensions undergo many organic transformations like Diel-Alder reaction, alkylation, Friedel-crafts, cross-coupling reaction, reduction, oxidation, cyclization, and lots of more [199]. Studies of researchers about silver nanoparticles, show exceptional or low selective reactions to highly transformations and selective chemical breakdown for various reactions catalyzed by nanosilver particles. For instance, energetically hard to achieve p-nitrophenol's reduction isn't possible even if we add strong reducing agent sodium borohydride $\left(\mathrm{NaBH}_{4}\right)$ and require a wait for a month. But, if nanoparticles of silver are allowed to add to the same mixture it can make the impossible reaction possible by producing p-aminophenol [200]. Researchers study, shows that Ag nanoparticles have the great ability of catalysis for the production of pharmaceutical and natural priducts [201].

\section{Biohazards}

Nanoparticles show relatively more toxicity as compared to macroparticles. They're cytotoxic to cells, organelles and also show toxicity to biological molecules [202]. At the cellular level on exposure to nanoparitcles shows oxidative stress and severe peroxidation of lipids. [203]. Reactive oxygen species are known to be the cause to produce cytotoxicity by silver nanoparticles through which reduction in the level of glutathione and increase in the level of reactive oxygen species.

Researchers have reported that surprisingly nanosilver particles cannot differentiate between bacteria of different strains and therefore kills even those microorganisms that are beneficial to different life forms [204]. Only a few studies are conducted to check the toxicity of nanosilver particles. According to one study in vitro on rats, showing that even a small amount of silvernanoparticles exposure resulted in the reduced rate of mitochondrial function linked to increased oxidative stress which ultimately creates toxicity [205]. The same results happened in mouse germline according to another study. According to researcher silver, NPs have also known to be toxic in vitro mouse germline cells as they also reduced the mitochondrial functioning which results in leakage through the cell membranes. Aggregates of nanosilver particles have shown to be more toxic to cells than asbestos [206]. Researchers have provided an information that shows silver ions causing changes in potassium and sodium ions permeability to the cell membrane at concentrations that don't even limit ATP, potassium, sodium, or mitochondrial activity [207]. Few studies have depicted that nanosilver can activate many toxic effects on the proliferation and cytokine expression by peripheral blood mononuclear cells [208]. Another biohazard of nanosilver is on the male genital system which shows its potentially toxic effect. A few type of researches indicate that silver NPs by crossing the barrier of blood-testes and can deposit inside the testicles where sperm cells got affected badly. [209].

It is observed that silver-based dressings available in the market also possess cytotoxic effects [210]. The oral toxicity of nanosilver on rats's liver in vivo conditions has been seen in a research work. In the histopathological study, it has been observed that there is more occurrence of CBD hyperplasia, with or without fibrosis and necrosis during the animal study [211]. Research also proved that by storage of nanoparticles over a period of a long time there is the 
Vol. 07, No. 01; 2022

ISSN: $2456-8643$

release of silver. Therefore, it is concluded that the old nanosilver is more dangerous and hazardous than the new nanosilver particles [212].

A few properties of nanosilver are responsible for its cytotoxicity that include particle size, agglomeration and sedimentation. It has been confirmed that the silver nanoparticles of $10 \mathrm{~nm}$ coated with polyvinyl povidone (PVP) and citrate are toxic to the cells of human lungs [213] as exposed for 24 hours. Although, the $\mathrm{AB}$ test used to measure cell proliferation and mitochondrial activity. On the other hand, the LDH test is used to confirm the cytotoxicity of silver nanoparticles during membrane damage from the cytoplasm [214, 215]. It has been shown that cytotoxicity is associated with enzyme inhibition that is due to the discharge of silver ions because they prevent the catalytic activity of lactate dehydrogenase (LDH).

During the study, it has been observed that DNA was damaged by silver nanoparticles but they did not increase reactive oxygen species (ROS) when cells were exposed to them for 24 hours at a dose of $20 \mu \mathrm{g} / \mathrm{mL}$ [214]. It has also been suggested that silver ions released from $\mathrm{AgCl}$ within the biological fluid and complexed [213]. The $\mathrm{AgCl}$ formation is feasible as long as the fluid is loaded with $\mathrm{Cl}^{-}$ions yet it can not dissociate to $\mathrm{Ag}^{+}$and $\mathrm{Cl}^{-}$ions because $\mathrm{AgCl}$ is insoluble in aqueous an medium [216]. Further, extracellularly released silver ions in the cell medium did not show toxicity, perhaps it might react with $\mathrm{Cl}^{-}$ions to produce insoluble $\mathrm{AgCl}$.

Carlson revealed that the $15 \mathrm{~nm}$ hydrocarbon coating of silver nanoparticles increased in reactive oxygen species (ROS) [217]. Liu has reported that $5 \mathrm{~nm}$ silver nanoparticles were more toxic than 20 and 50 nanoparticles to four cell lines are HePG2, MCF-7, SGC-7901 and A 549 [217]. Wang demonstrated that smaller nanoparticles $(10-20 \mathrm{~nm})$ cause more cytotoxicity than larger ones $(110 \mathrm{~nm})$, and citrated coated silver nanoparticles produce severe neutrophilic inflammation in the lungs of mice as compared to those with larger ones [218], also cell feasibility and DNA break can be confirmed by ROS generation [219], which might look contradictory to reports by others researchers in vitro studies [220].

It is assumed that DNA rupturing is because of the disruption of silver nanoparticles with repair pathways in vitro study of DNA, once DNA is damaged then can not be recovered again. As we know the living cells are capable to repair and proliferate. Generally, we can understand that both the nanoparticles of silver and its ions existing at the subcellular levels. The change of silver to $\mathrm{Ag}+$ ions occurs inside the cell membrane because of various biological processes. The elemental Ag discharge is directly related to the dimensions of nanoparticles [221]. In another research, it is reported that the dimensions dependent toxicity are said to be because of the intracellular release of silver ions. Another observation regarding silver nanoparticles is that the antibacterial effect was restricted under anaerobic conditions reason being the oxidation reaction i.e., silver to Ag plus ions conversion stops under anaerobic conditions . Silver NPs have great action against the P. vulgaris, Y. enterocolitica, E. coli, S. faecalis and S. aureus. As nanoparticles are smaller in dimensions than the bacterial cell they stick with cell walls resulting in a hindered flow of nutrients across the membrane causing microbial death [222]. So, it is deduced that greater concentration around the cell wall ceases the cellular division of microorganisms.

Researchers investigated that nanosilver due to its antimicrobial activity, can adversely influence soil friendly bacteria that exhibit toxic effects on denitrifying bacteria, silver can disturb the denitrification process in which the conversion of nitrates into nitrogen gas takes place. The environmental denitrification disruption occurs by the reduction of plant growth that finally 
causes eutrophication of marine ecosystem, lakes rivers and ecosystem is also destroyed [223]. The silver ions also affect aquatic animals and, in particular interact with the gills of fish and show Na+-K+-ATPase activity, which can inhibit osmoregulation within the fish [224]. Daphnia Magna 48-h immobilization test was conducted to check the toxic effect of silver nanoparticles in freshwater test thus the silver nanoparticles are classified under category acute 1 as per Globally Harmonized System of Classification and Labelling of Chemicals [225]. In vivo and vitro conditions it has been observed that the silver nanoparticles can cause toxicity to live organisms. Therefore more studies especially in vitro need to be done before declaring nanosilver particles as hazardous ones.

It is also noticed that the combination of silver nanoparticles with antibiotics reduce the toxicity to human cells by reducing the specified quantity [226]. Silver nanoparticles show antimicrobial behaviour against microorganisms either alone or in combination and also effective for killing resistant bacteria [227]. It is seen through experiment E.coli shows resistant against silver nanoparticles on its regular exposure for 225 generations through genetic change [228]. So, it is necessaryt to take preventive measures in order to keep away from the risk of continued exposure to microbes. Further, it is also observed the silver nanoparticles produced from bacterial species show cytotoxicity to cancer cells. The cell ability to function is reduced during a dose-depenendent mode in a mode in HeLa cancer of cervics [229], A549 adenocarcinoma (malignant tumor) cancer of lungs [230], MDA-MB-231 cancer of breast [231] and HEP2 [232] cell lines. In many studies, it has been noticed that silver nanoparticles are harmful for nitrogen fixation [233]. Excessive reactive oxygen species like hydroxyl $(\cdot \mathrm{OH})$, superoxide $(\mathrm{O} 2-)$, peroxy (RCOO.) and hydrogen peroxide ( $\mathrm{H} 2 \mathrm{O} 2)$ can damage the cellular protein and are considered a carcinogen. The reactive nitrogen species as nitric oxide (NO-) and nitrogen dioxide (NO2-) [234, 235]. The environment which is contaminated with ROS may stop cell replication and development. However, the presence of an antioxidant like an enzyme or a non-enzymatic component that scavenges the free radicals can delay the cell-damaging process [236].

\section{Acknowledgement}

I (Muhammad Amjad) would like to say special thanks to Dr.Shabbir Hussain, Department of Chemistry, Khwaja Fareed University of Engineering and Information Technology, Rahim Yar Khan-Pakistan who guided for the completion of this aricle.

\section{CONCLUSION}

The above review covers a comparison between the different modes of Ag nanoparticles synthesis and its great number of applications. This review highlights the evolving area in the discipline of nanoscience and the researcher's hard work on plant-mediated biosynthesis of Ag NPs. It explores the benefits for future researchers due to its gradual increase in the field of publications. This paper contains new ideas for pharmacists due to its great number of applications in the field like larvicides, anticancer drugs, biological tools and devices that contain these exciting Nanosilver particles. Hence, nanoparticle synthesis biologically has played a significant role in the field bionanomedicine and its dominance has also been acknowledged by other fields. Although, the persistency of nanoparticles is confirmed their effect on human body health and food products through clothes, paints, medicines etc. are not clear yet but they might reach through sewage and sludge to our crops. In spite of its great number of advantages there 
Vol. 07, No. 01; 2022

ISSN: $2456-8643$

few disadvantages of using nanoparticles of Ag. Researchers showed that they reduce the nitrifying bacteria's growth and ultimately reduces the removal of biological nitrogen from the sources and for this little amount of Ag NPs is enough. There are studies that prove that Nano silver particles can cause serious damage to the ecosystem if they are allowed to release freely in the natural environment. So, this review is concluded with that precautionary measurements must be taken in order to avail the benefits from these exciting nanoparticles by spreading awareness among the people for its level of safe usage, by keeping the limits of its utilization in mind and ultimately all these things will help us to eliminate its hazardous effects from the environment.

\section{REFERENCES}

1. Hussain, S. and M. Amjad, A Review on Gold Nanoparticles (GNPs) and their Advancement in Cancer Therapy. International Journal of Nanomaterials, Nanotechnology and Nanomedicine, 2021. 7(1): p. 019-025.

2. Hussain, S., et al., A Perspective Study on Copper Oxide Nanoparticles and Their Role in Different Fields of Biomedical Sciences. International Journal of Scientific Research and Engineering Development, 2020. 3(6): p. 1246-1256.

3. Rehman, H., et al., Synthesis and characterization of $\mathrm{ZnO}$ nanoparticles and their use as an adsorbent for the arsenic removal from drinking water. Digest Journal of Nanomaterials and Biostructures, 2019. 14(4): p. 1033-1040.

4. Munir, M., et al., The Role of Nanoparticles in the Diagnosis and Treatment of Diseases. Scientific Inquiry and Review, 2020. 4(3): p. 14-26.

5. Zulfiqar, H., et al., Nature of nanoparticles and their applications in targeted drug delivery. Pakistan Journal of Science, 2020. 72(1): p. 30.

6. De, M., P.S. Ghosh, and V.M. Rotello, Applications of nanoparticles in biology. Advanced Materials, 2008. 20(22): p. 4225-4241.

7. Singh, R. and H.S. Nalwa, Medical applications of nanoparticles in biological imaging, cell labeling, antimicrobial agents, and anticancer nanodrugs. Journal of biomedical nanotechnology, 2011. 7(4): p. 489-503.

8. Raza, M.W., et al., Strategy to enhance the electrochemical characteristics of lanthanum sulfide nanorods for supercapacitor applications. Journal of Nanoparticle Research, 2021. 23(9): p. 1-12.

9. Abbas, S.M., et al., High rate capability and long cycle stability of $\mathrm{Cr} 2 \mathrm{O} 3$ anode with CNTs for lithium ion batteries. Electrochimica Acta, 2016. 212: p. 260-269.

10. Shahzad, K., Synthesis, Characterization, and Photocatalytic Degradation of Nickel Doped Copper Oxide Nanoparticles. LGUJLS, 2020. 4(02): p. 130-138.

11. Javed, M., et al., Synthesis, characterization and photocatalytic applications of s-doped graphitic carbon nitride nanocomposites with nickel doped zinc oxide nanoparticles. Digest Journal of Nanomaterials and Biostructures, 2020. 15(4): p. 1097-1105.

12. Patra, J.K. and K.-H. Baek, Green nanobiotechnology: factors affecting synthesis and characterization techniques. Journal of Nanomaterials, 2014. 2014: p. 219.

13. Veerasamy, R., et al., Biosynthesis of silver nanoparticles using mangosteen leaf extract and evaluation of their antimicrobial activities. J Saudi Chem Soc 15 (2): 113-120. 2011.

14. Mohan, S., et al., Completely green synthesis of dextrose reduced silver nanoparticles, its antimicrobial and sensing properties. Carbohydrate polymers, 2014. 106: p. 469-474. 
15. Sharma, V.K., R.A. Yngard, and Y. Lin, Silver nanoparticles: green synthesis and their antimicrobial activities. Advances in colloid and interface science, 2009. 145(1-2): p. 8396.

16. Nosheen, S., et al., A review: Development of magnetic nano vectors for biomedical applications. GSC Advanced Research and Reviews, 2021. 8(2): p. 085-110.

17. Collera-Zúñiga, O., F.G. Jiménez, and R.M. Gordillo, Comparative study of carotenoid composition in three mexican varieties of Capsicum annuum L. Food Chemistry, 2005. 90(1-2): p. 109-114.

18. Ghaffari-Moghaddam, M. and R. Hadi-Dabanlou, Plant mediated green synthesis and antibacterial activity of silver nanoparticles using Crataegus douglasii fruit extract. Journal of Industrial and Engineering Chemistry, 2014. 20(2): p. 739-744.

19. Dahl, J.A., B.L. Maddux, and J.E. Hutchison, Toward greener nanosynthesis. Chemical reviews, 2007. 107(6): p. 2228-2269.

20. Kim, J.S., et al., Antimicrobial effects of silver nanoparticles. Nanomedicine: Nanotechnology, biology and medicine, 2007. 3(1): p. 95-101.

21. Christian, P., et al., Nanoparticles: structure, properties, preparation and behaviour in environmental media. Ecotoxicology, 2008. 17(5): p. 326-343.

22. Iravani, S., Green synthesis of metal nanoparticles using plants. Green Chemistry, 2011. 13(10): p. 2638-2650.

23. Rai, M., A. Yadav, and A. Gade, Silver nanoparticles as a new generation of antimicrobials. Biotechnology advances, 2009. 27(1): p. 76-83.

24. Schultz, S., et al., Single-target molecule detection with nonbleaching multicolor optical immunolabels. Proceedings of the National Academy of Sciences, 2000. 97(3): p. 9961001.

25. Gittins, D.I., et al., A nanometre-scale electronic switch consisting of a metal cluster and redox-addressable groups. Nature, 2000. 408(6808): p. 67.

26. Crooks, R.M., et al., Dendrimer-encapsulated metals and semiconductors: synthesis, characterization, and applications, in Dendrimers III. 2001, Springer. p. 81-135.

27. Sengupta, S., et al., Temporal targeting of tumour cells and neovasculature with a nanoscale delivery system. Nature, 2005. 436(7050): p. 568.

28. Reddy, G., et al., Nano silver-a review. Int J Adv Pharm, 2012. 2(1): p. 09-15.

29. Kiran, A., et al., Catalytic degradation of methylene blue using a newly engineered composite and its electrochemical performance. Case Studies in Chemical and Environmental Engineering, 2020. 2: p. 100039.

30. Javed, M. and S. Hussain, Synthesis, characterization and photocatalytic applications of $p$ (aac) microgels and its composites of ni doped $\mathrm{ZnO}$ nanorods. Dig J Nanomater Bios, 2020. 15(1): p. 217-30.

31. Iqbal, M., et al., Recycling of lead from lead acid battery to form composite material as an anode for low temperature solid oxide fuel cell. Materials Today Energy, 2020. 16: p. 100418.

32. Javed, M., et al., Amino-functionalized silica anchored to multiwall carbon nanotubes as hybrid electrode material for supercapacitors. Materials Science for Energy Technologies, 2018. 1(1): p. 70-76. 
33. Javeda, M., et al., Synthesis and characterization of nanoparticles derived from chitosanbased biopolymer; their photocatalytic and anti-termite potential. Digest Journal of Nanomaterials and Biostructures. 16(4): p. 1607-1618.

34. Kandakumar, S., V. Sathya, and V. Manju, Synthesis and characterization of silver nanoparticles using Hydnocarpus alpina, its application as A potent antimicrobial and antioxidant agent - a novel study. Int. J. Chem. Tech. Res, 2014. 6: p. 4770-4776.

35. Schneidewind, H., et al., The morphology of silver nanoparticles prepared by enzymeinduced reduction. Beilstein journal of nanotechnology, 2012. 3(1): p. 404-414.

36. Kouvaris, P., et al., Green synthesis and characterization of silver nanoparticles produced using Arbutus unedo leaf extract. Materials Letters, 2012. 76: p. 18-20.

37. Jha, A.K. and K. Prasad, Green synthesis of silver nanoparticles using Cycas leaf. International Journal of Green Nanotechnology: Physics and Chemistry, 2010. 1(2): p. P110-P117.

38. Ramesh, P., T. Kokila, and D. Geetha, Plant mediated green synthesis and antibacterial activity of silver nanoparticles using Emblica officinalis fruit extract. Spectrochimica Acta Part A: Molecular and Biomolecular Spectroscopy, 2015. 142: p. 339-343.

39. Božanić, D.K., et al., 'Green'synthesis and optical properties of silver-chitosan complexes and nanocomposites. Reactive and functional polymers, 2010. 70(11): p. 869873.

40. Raveendran, P., J. Fu, and S.L. Wallen, A simple and "green" method for the synthesis of $A u, A g$, and $A u-A g$ alloy nanoparticles. Green Chemistry, 2006. 8(1): p. 34-38.

41. Mazloom, F., et al., Novel sodium dodecyl sulfate-assisted synthesis of Zn3V2O8 nanostructures via a simple route. Journal of Molecular Liquids, 2016. 214: p. 46-53.

42. Roy, N., et al., Green synthesis of silver nanoparticles: an approach to overcome toxicity. Environmental Toxicology and Pharmacology, 2013. 36(3): p. 807-812.

43. Thakkar, K.N., S.S. Mhatre, and R.Y. Parikh, Biological synthesis of metallic nanoparticles. Nanomedicine: Nanotechnology, Biology and Medicine, 2010. 6(2): p. 257-262.

44. Kalishwaralal, K., et al., Extracellular biosynthesis of silver nanoparticles by the culture supernatant of Bacillus licheniformis. Materials letters, 2008. 62(29): p. 4411-4413.

45. Parashar, U.K., P.S. Saxena, and A. Srivastava, Bioinspired synthesis of silver nanoparticles. Digest Journal of Nanomaterials \& Biostructures (DJNB), 2009. 4(1).

46. Das, V.L., et al., Extracellular synthesis of silver nanoparticles by the Bacillus strain CS 11 isolated from industrialized area. 3 Biotech, 2014. 4(2): p. 121-126.

47. Liu, B., et al., Optimization of high-yield biological synthesis of single-crystalline gold nanoplates. The Journal of Physical Chemistry B, 2005. 109(32): p. 15256-15263.

48. Willner, I., R. Baron, and B. Willner, Growing metal nanoparticles by enzymes. Advanced Materials, 2006. 18(9): p. 1109-1120.

49. Jha, A.K., et al., Plant system: nature's nanofactory. Colloids and Surfaces B: Biointerfaces, 2009. 73(2): p. 219-223.

50. Kumar, B., et al., Capuli cherry-mediated green synthesis of silver nanoparticles under white solar and blue LED light. Particuology, 2016. 24: p. 123-128.

51. Kumar, B., et al., Synthesis of silver nanoparticles using Sacha inchi (Plukenetia volubilis L.) leaf extracts. Saudi journal of biological sciences, 2014. 21(6): p. 605-609. 
52. Mehmood, A., et al., Antibacterial efficacy of silver nanoparticles synthesized by a green method using bark extract of Melia azedarach L. Journal of Pharmaceutical Innovation, 2014. 9(3): p. 238-245.

53. Kumar, B., et al., Sacha inchi (Plukenetia volubilis L.) oil for one pot synthesis of silver nanocatalyst: an ecofriendly approach. Industrial Crops and Products, 2014. 58: p. 238243.

54. Kumar, B., et al., Fabrication of silver nanoplates using Nephelium lappaceum (Rambutan) peel: a sustainable approach. Journal of Molecular Liquids, 2015. 211: p. 476-480.

55. Shameli, K., et al., Green biosynthesis of silver nanoparticles using Curcuma longa tuber powder. International journal of nanomedicine, 2012. 7: p. 5603.

56. Nalvothula, R., et al., Biogenic synthesis of silver nanoparticles using Tectona grandis leaf extract and evaluation of their antibacterial potential. Int J ChemTech Res, 2014. 6(1): p. 293-298.

57. Zuas, O., N. Hamim, and Y. Sampora, Bio-synthesis of silver nanoparticles using water extract of Myrmecodia pendan (Sarang Semut plant). Materials Letters, 2014. 123: p. 156-159.

58. Mittal, A.K., et al., Biosynthesis of silver nanoparticles: elucidation of prospective mechanism and therapeutic potential. Journal of colloid and interface science, 2014. 415: p. 39-47.

59. Prathap, M., A. Alagesan, and B.R. Kumari, Anti-bacterial activities of silver nanoparticles synthesized from plant leaf extract of Abutilon indicum (L.) Sweet. Journal of Nanostructure in Chemistry, 2014. 4(3): p. 106.

60. Daniel, S., et al., Green synthesis and transfer of silver nanoparticles in a food chain through Chiranamous Larva to zebra fish-a new approach for therapeutics. International Journal of Nanoscience and Nanotechnology, 2011. 2(3): p. 159-169.

61. Nayak, D., et al., Biologically synthesised silver nanoparticles from three diverse family of plant extracts and their anticancer activity against epidermoid A431 carcinoma. Journal of colloid and interface science, 2015. 457: p. 329-338.

62. Joseph, S. and B. Mathew, Microwave assisted facile green synthesis of silver and gold nanocatalysts using the leaf extract of Aerva lanata. Spectrochimica Acta Part A: Molecular and Biomolecular Spectroscopy, 2015. 136: p. 1371-1379.

63. Saxena, A., R. Tripathi, and R. Singh, Biological synthesis of silver nanoparticles by using onion (Allium cepa) extract and their antibacterial activity. Dig J Nanomater Bios, 2010. 5(2): p. 427-432.

64. Von White, G., et al., Green synthesis of robust, biocompatible silver nanoparticles using garlic extract. Journal of Nanomaterials, 2012. 2012: p. 55.

65. Chandran, S.P., et al., Synthesis of gold nanotriangles and silver nanoparticles using Aloevera plant extract. Biotechnology progress, 2006. 22(2): p. 577-583.

66. Shetty, P., et al., Synthesis, characterization and antimicrobial activity of Alstonia scholaris bark-extract-mediated silver nanoparticles. Journal of Nanostructure in Chemistry, 2014. 4(4): p. 161-170. 
67. Sulochana, S., P. Krishnamoorthy, and K. Sivaranjani, Synthesis of silver nanoparticles using leaf extract of Andrographis paniculata. J Pharmacol Toxicol, 2012. 7(5): p. 251258.

68. Santhosh, S., R. Yuvarajan, and D. Natarajan, Annona muricata leaf extract-mediated silver nanoparticles synthesis and its larvicidal potential against dengue, malaria and filariasis vector. Parasitology research, 2015. 114(8): p. 3087-3096.

69. Murugan, K., et al., Aristolochia indica green-synthesized silver nanoparticles: $A$ sustainable control tool against the malaria vector Anopheles stephensi? Research in veterinary science, 2015. 102: p. 127-135.

70. Jagtap, U.B. and V.A. Bapat, Green synthesis of silver nanoparticles using Artocarpus heterophyllus Lam. seed extract and its antibacterial activity. Industrial crops and products, 2013. 46: p. 132-137.

71. Saikia, D., et al., Green synthesis of silver nanoparticles using Asiatic Pennywort and Bryophyllum leaves extract and their antimicrobial activity. Adv. Mater. Lett, 2015. 6(3): p. 260-264.

72. Kora, A.J. and J. Arunachalam, Green fabrication of silver nanoparticles by gum Tragacanth (Astragalus gummifer): a dual functional reductant and stabilizer. Journal of Nanomaterials, 2012. 2012: p. 69.

73. Zhang, D., et al., Synthesis of needle-like nickel nanoparticles in water-in-oil microemulsion. Materials Letters, 2005. 59(16): p. 2011-2014.

74. Shankar, S.S., et al., Rapid synthesis of Au, Ag, and bimetallic Au core-Ag shell nanoparticles using Neem (Azadirachta indica) leaf broth. Journal of colloid and interface science, 2004. 275(2): p. 496-502.

75. Raja, S., V. Ramesh, and V. Thivaharan, Green biosynthesis of silver nanoparticles using Calliandra haematocephala leaf extract, their antibacterial activity and hydrogen peroxide sensing capability. Arabian journal of chemistry, 2017. 10(2): p. 253-261.

76. Rajkuberan, C., et al., Antibacterial and cytotoxic potential of silver nanoparticles synthesized using latex of Calotropis gigantea L. Spectrochimica Acta Part A: Molecular and Biomolecular Spectroscopy, 2015. 136: p. 924-930.

77. Mohamed, N.H., et al., Antimicrobial activity of latex silver nanoparticles using Calotropis procera. Asian Pacific Journal of Tropical Biomedicine, 2014. 4(11): p. 876883.

78. $\quad \mathrm{Li}, \mathrm{S}$., et al., Green synthesis of silver nanoparticles using Capsicum annuum L. extract. Green Chemistry, 2007. 9(8): p. 852-858.

79. Mude, N., et al., Synthesis of silver nanoparticles using callus extract of Carica papayaa first report. Journal of Plant Biochemistry and Biotechnology, 2009. 18(1): p. 83-86.

80. Dwivedi, A.D. and K. Gopal, Plant-mediated biosynthesis of silver and gold nanoparticles. Journal of biomedical nanotechnology, 2011. 7(1): p. 163-164.

81. Huang, J., et al., Biosynthesis of silver and gold nanoparticles by novel sundried Cinnamomum camphora leaf. Nanotechnology, 2007. 18(10): p. 105104.

82. Sathishkumar, M., et al., Cinnamon zeylanicum bark extract and powder mediated green synthesis of nano-crystalline silver particles and its bactericidal activity. Colloids and Surfaces B: Biointerfaces, 2009. 73(2): p. 332-338. 
83. Satyavani, K., T. Ramanathan, and S. Gurudeeban, Plant mediated synthesis of biomedical silver nanoparticles by using leaf extract of Citrullus colocynthis. Research journal of nanoscience and nanotechnology, 2011. 1(2): p. 95-101.

84. Mohapatra, B., et al., Biosynthesis of high concentration, stable aqueous dispersions of silver nanoparticles using Citrus limon extract. Advanced Materials Letters, 2015. 6(3): p. 228-234.

85. Raman, R.P., et al., Biogenic silver nanoparticles synthesis using the extract of the medicinal plant Clerodendron serratum and its in-vitro antiproliferative activity. Materials Letters, 2015. 160: p. 400-403.

86. Roopan, S.M., et al., Low-cost and eco-friendly phyto-synthesis of silver nanoparticles using Cocos nucifera coir extract and its larvicidal activity. Industrial Crops and Products, 2013. 43: p. 631-635.

87. Vanaja, M. and G. Annadurai, Coleus aromaticus leaf extract mediated synthesis of silver nanoparticles and its bactericidal activity. Applied Nanoscience, 2013. 3(3): p. 217-223.

88. Sathyavathi, R., et al., Biosynthesis of silver nanoparticles using Coriandrum sativum leaf extract and their application in nonlinear optics. Advanced science letters, 2010. 3(2): p. 138-143.

89. Roy, K., C. Sarkar, and C. Ghosh, SINGLE-STEP NOVEL BIOSYNTHESIS OF SILVER NANOPARTICLES USING CUCUMIS SATIVUS FRUIT EXTRACT AND STUDY OF ITS PHOTCATALYTIC AND ANTIBACTERIAL ACTIVITY. Digest Journal of Nanomaterials \& Biostructures (DJNB), 2015. 10(1).

90. Kesharwani, J., et al., Phytofabrication of silver nanoparticles by leaf extract of Datura metel: hypothetical mechanism involved in synthesis. Journal of Bionanoscience, 2009. 3(1): p. 39-44.

91. Ahmad, N., et al., Biosynthesis of silver nanoparticles from Desmodium triflorum: $a$ novel approach towards weed utilization. Biotechnology Research International, 2011. 2011.

92. Ghosh, S., et al., Synthesis of silver nanoparticles using Dioscorea bulbifera tuber extract and evaluation of its synergistic potential in combination with antimicrobial agents. International journal of nanomedicine, 2012. 7: p. 483.

93. Maheswari, R.U., et al., Green synthesis of silver nanoparticles by using rhizome extract of Dioscorea oppositifolia $L$. and their anti microbial activity against human pathogens. $\mathrm{J}$ Pharm Biol Sci, 2012. 1: p. 38-42.

94. Yousefzadi, M., Z. Rahimi, and V. Ghafori, The green synthesis, characterization and antimicrobial activities of silver nanoparticles synthesized from green alga Enteromorpha flexuosa (wulfen) J. Agardh. Materials Letters, 2014. 137: p. 1-4.

95. Sulaiman, G.M., et al., Green synthesis, antimicrobial and cytotoxic effects of silver nanoparticles using Eucalyptus chapmaniana leaves extract. Asian Pacific journal of tropical biomedicine, 2013. 3(1): p. 58-63.

96. Ali, K., et al., Microwave accelerated green synthesis of stable silver nanoparticles with Eucalyptus globulus leaf extract and their antibacterial and antibiofilm activity on clinical isolates. PloS one, 2015. 10(7): p. e0131178. 
97. Nasrollahzadeh, M., et al., Euphorbia helioscopia Linn as a green source for synthesis of silver nanoparticles and their optical and catalytic properties. Journal of colloid and interface science, 2015. 450: p. 374-380.

98. Priya, M.M., B.K. Selvi, and J. Paul, Green synthesis of silver nanoparticles from the leaf extracts of Euphorbia hirta and Nerium indicum. Digest Journal of Nanomaterials \& Biostructures (DJNB), 2011. 6(2).

99. Bhuvaneswari, R., R.J. Xavier, and M. Arumugam, Facile synthesis of multifunctional silver nanoparticles using mangrove plant Excoecaria agallocha L. for its antibacterial, antioxidant and cytotoxic effects. Journal of parasitic diseases, 2017. 41(1): p. 180-187.

100. Borase, H.P., et al., Innovative approach for urease inhibition by Ficus carica extractfabricated silver nanoparticles: An in vitro study. Biotechnology and applied biochemistry, 2015. 62(6): p. 780-784.

101. Dinesh, S., S. Karthikeyan, and P. Arumugam, Biosynthesis of silver nanoparticles from Glycyrrhiza glabra root extract. Archives of applied science research, 2012. 4(1): p. 178187.

102. Sana, S.S., et al., Eco-friendly synthesis of silver nanoparticles using leaf extract of Grewia flaviscences and study of their antimicrobial activity. Materials Letters, 2015. 145: p. 347-350.

103. Bhakya, S., et al., Biogenic synthesis of silver nanoparticles and their antioxidant and antibacterial activity. Applied Nanoscience, 2016. 6(5): p. 755-766.

104. Latha, M., et al., Biocatalytic and antibacterial visualization of green synthesized silver nanoparticles using Hemidesmus indicus. Microbial pathogenesis, 2015. 82: p. 43-49.

105. Bindhu, M. and M. Umadevi, Synthesis of monodispersed silver nanoparticles using Hibiscus cannabinus leaf extract and its antimicrobial activity. Spectrochimica Acta Part A: Molecular and Biomolecular Spectroscopy, 2013. 101: p. 184-190.

106. Philip, D., Green synthesis of gold and silver nanoparticles using Hibiscus rosa sinensis. Physica E: Low-Dimensional Systems and Nanostructures, 2010. 42(5): p. 1417-1424.

107. Yadav, A. and M. Rai, Bioreduction and mechanistic aspects involved in the synthesis of silver nanoparticles using Holarrhena antidysenterica. Journal of Bionanoscience, 2011. 5(1): p. 70-73.

108. Das, S., et al., Biosynthesized silver nanoparticles by ethanolic extracts of Phytolacca decandra, Gelsemium sempervirens, Hydrastis canadensis and Thuja occidentalis induce differential cytotoxicity through G2/M arrest in A375 cells. Colloids and Surfaces B: Biointerfaces, 2013. 101: p. 325-336.

109. SABLE, N., et al., Phytofabrication of silver nanoparticles by using aquatic plant Hydrilla verticillata. Nusantara Bioscience, 2012. 4(2).

110. Roni, M., et al., Characterization and biotoxicity of Hypnea musciformis-synthesized silver nanoparticles as potential eco-friendly control tool against Aedes aegypti and Plutella xylostella. Ecotoxicology and environmental safety, 2015. 121: p. 31-38.

111. Bar, H., et al., Green synthesis of silver nanoparticles using latex of Jatropha curcas. Colloids and surfaces A: Physicochemical and engineering aspects, 2009. 339(1-3): p. 134-139. 
112. Bose, D. and S. Chatterjee, Antibacterial activity of green synthesized silver nanoparticles using Vasaka (Justicia adhatoda L.) leaf extract. Indian journal of microbiology, 2015. 55(2): p. 163-167.

113. Sivakumar, P., C. Nethradevi, and S. Renganathan, Synthesis of silver nanoparticles using Lantana camara fruit extract and its effect on pathogens. Asian J Pharm Clin Res, 2012. 5(3): p. 97-101.

114. Im, A.R., et al., Enhanced antibacterial activities of Leonuri herba extracts containing silver nanoparticles. Phytotherapy research, 2012. 26(8): p. 1249-1255.

115. Maiti, S., et al., Antimicrobial activities of silver nanoparticles synthesized from Lycopersicon esculentum extract. Journal of analytical science and technology, 2014. 5(1): p. 40.

116. Gardea-Torresdey, J.L., et al., Alfalfa sprouts: a natural source for the synthesis of silver nanoparticles. Langmuir, 2003. 19(4): p. 1357-1361.

117. MubarakAli, D., et al., Plant extract mediated synthesis of silver and gold nanoparticles and its antibacterial activity against clinically isolated pathogens. Colloids and Surfaces B: Biointerfaces, 2011. 85(2): p. 360-365.

118. Swamy, M.K., et al., Synthesis and characterization of silver nanoparticles using fruit extract of Momordica cymbalaria and assessment of their in vitro antimicrobial, antioxidant and cytotoxicity activities. Spectrochimica Acta Part A: Molecular and Biomolecular Spectroscopy, 2015. 151: p. 939-944.

119. Suman, T., et al., Biosynthesis, characterization and cytotoxic effect of plant mediated silver nanoparticles using Morinda citrifolia root extract. Colloids and surfaces B: Biointerfaces, 2013. 106: p. 74-78.

120. Jancy, M.E. and L. Inbathamizh, Green synthesis and characterization of nano silver using leaf extract of Morinda pubescens. Asian journal of pharmaceutical and clinical research, 2012. 5(1): p. 159-162.

121. Vanaja, M., et al., Degradation of methylene blue using biologically synthesized silver nanoparticles. Bioinorganic chemistry and applications, 2014. 2014.

122. Chitra, G., et al., Mukia maderaspatana (Cucurbitaceae) extract-mediated synthesis of silver nanoparticles to control Culex quinquefasciatus and Aedes aegypti (Diptera: Culicidae). Parasitology research, 2015. 114(4): p. 1407-1415.

123. Banerjee, P., et al., Leaf extract mediated green synthesis of silver nanoparticles from widely available Indian plants: synthesis, characterization, antimicrobial property and toxicity analysis. Bioresources and Bioprocessing, 2014. 1(1): p. 3.

124. Sharma, G., et al., GREEN SYNTHESIS OF SILVER NANOPARTICLE USING MYRISTICA FRAGRANS (NUTMEG) SEED EXTRACT AND ITS BIOLOGICAL ACTIVITY. Digest Journal of Nanomaterials \& Biostructures (DJNB), 2014. 9(1).

125. Sreekanth, T., S. Ravikumar, and I.-Y. Eom, Green synthesized silver nanoparticles using Nelumbo nucifera root extract for efficient protein binding, antioxidant and cytotoxicity activities. Journal of Photochemistry and Photobiology B: Biology, 2014. 141: p. 100-105.

126. Ahmad, N., et al., Rapid synthesis of silver nanoparticles using dried medicinal plant of basil. Colloids and Surfaces B: Biointerfaces, 2010. 81(1): p. 81-86. 
Vol. 07, No. 01; 2022

ISSN: $2456-8643$

127. Nezamdoost, T., M. Bagherieh-Najjar, and M. Aghdasi, Biogenic synthesis of stable bioactive silver chloride nanoparticles using Onosma dichroantha Boiss. root extract. Materials Letters, 2014. 137: p. 225-228.

128. Mollick, M.M.R., et al., Green synthesis of silver nanoparticles using Paederia foetida $L$. leaf extract and assessment of their antimicrobial activities. International Journal of Green Nanotechnology, 2012. 4(3): p. 230-239.

129. Kumar, D., Rapid and green synthesis of silver nanoparticles using the leaf extracts of Parthenium hysterophorus: a novel biological approach. Int Res J Pharm, 2012. 3(2): p. 169-172.

130. Sundaravadivelan, C. and M. Nalini, Biolarvicidal effect of phyto-synthesized silver nanoparticles using Pedilanthus tithymaloides (L.) Poit stem extract against the dengue vector Aedes aegypti L.(Diptera; Culicidae). Asian Pac J Trop Biomed, 2012: p. 1-8.

131. Suresh, U., et al., Tackling the growing threat of dengue: Phyllanthus niruri-mediated synthesis of silver nanoparticles and their mosquitocidal properties against the dengue vector Aedes aegypti (Diptera: Culicidae). Parasitology research, 2015. 114(4): p. 15511562.

132. betle Broth, P., Phytofabrication and characterization of silver nanoparticles from Piper betle broth. Research Journal of Nanoscience and nanotechnology, 2012. 2(1): p. 17-23.

133. Reddy, N.J., et al., Evaluation of antioxidant, antibacterial and cytotoxic effects of green synthesized silver nanoparticles by Piper longum fruit. Materials Science and Engineering: C, 2014. 34: p. 115-122.

134. Tamuly, C., et al., Biosynthesis of Ag nanoparticles using pedicellamide and its photocatalytic activity: an eco-friendly approach. Spectrochimica Acta Part A: Molecular and Biomolecular Spectroscopy, 2014. 132: p. 687-691.

135. Manikandan, D., D.G. Prakash, and N.N. Gandhi, A rapid and green route to synthesis of silver nanoparticles from Plectranthus barbatus (coleus forskohlii) root extract for antimicrobial activity. Int J Chem Tech Res, 2014. 6: p. 4391-4396.

136. Patil, C.D., et al., Larvicidal activity of silver nanoparticles synthesized using Plumeria rubra plant latex against Aedes aegypti and Anopheles stephensi. Parasitology research, 2012. 110(5): p. 1815-1822.

137. Raut, R.W., et al., Extracellular synthesis of silver nanoparticles using dried leaves of Pongamia pinnata (L) pierre. Nano-Micro Letters, 2010. 2(2): p. 106-113.

138. Mittal, A.K., et al., Bio-synthesis of silver nanoparticles using Potentilla fulgens Wall. ex Hook. and its therapeutic evaluation as anticancer and antimicrobial agent. Materials Science and Engineering: C, 2015. 53: p. 120-127.

139. Miri, A., et al., Plant-mediated biosynthesis of silver nanoparticles using Prosopis farcta extract and its antibacterial properties. Spectrochimica Acta Part A: Molecular and Biomolecular Spectroscopy, 2015. 141: p. 287-291.

140. Raghunandan, D., et al., Microwave-assisted rapid extracellular synthesis of stable biofunctionalized silver nanoparticles from guava (Psidium guajava) leaf extract. Journal of Nanoparticle Research, 2011. 13(5): p. 2021-2028.

141. Lokina, S., et al., Cytotoxicity and antimicrobial studies of silver nanoparticles synthesized using Psidium guajava L. extract. Synthesis and Reactivity in Inorganic, Metal-Organic, and Nano-Metal Chemistry, 2015. 45(3): p. 426-432. 
142. Korbekandi, H., et al., Green biosynthesis of silver nanoparticles using Quercus brantii (oak) leaves hydroalcoholic extract. Pharmaceutical biology, 2015. 53(6): p. 807-812.

143. Arokiyaraj, S., et al., Green synthesis of silver nanoparticles using Rheum palmatum root extract and their antibacterial activity against Staphylococcus aureus and Pseudomonas aeruginosa. Artificial cells, nanomedicine, and biotechnology, 2017. 45(2): p. 372-379.

144. Ghaedi, M., et al., Rosmarinus officinalis leaf extract mediated green synthesis of silver nanoparticles and investigation of its antimicrobial properties. Journal of Industrial and Engineering Chemistry, 2015. 31: p. 167-172.

145. Perugu, S., V. Nagati, and M. Bhanoori, Green synthesis of silver nanoparticles using leaf extract of medicinally potent plant Saraca indica: a novel study. Applied Nanoscience, 2016. 6(5): p. 747-753.

146. Nagajyoti, P., et al., BIO-FABRICATION OF SILVER NANOPARTICLES USING LEAF EXTRACT OF SAURURUS CHINENIS. Digest Journal of Nanomaterials \& Biostructures (DJNB), 2011. 6(1).

147. Nabikhan, A., et al., Synthesis of antimicrobial silver nanoparticles by callus and leaf extracts from saltmarsh plant, Sesuvium portulacastrum L. Colloids and surfaces B: Biointerfaces, 2010. 79(2): p. 488-493.

148. Khatami, M., et al., Synthesis of silver nanoparticles using seed exudates of Sinapis arvensis as a novel bioresource, and evaluation of their antifungal activity. Bioresources and Bioprocessing, 2015. 2(1): p. 19.

149. Ramar, M., et al., Synthesis of silver nanoparticles using Solanum trilobatum fruits extract and its antibacterial, cytotoxic activity against human breast cancer cell line MCF 7. Spectrochimica Acta Part A: Molecular and Biomolecular Spectroscopy, 2015. 140: p. 223-228.

150. Amin, M., et al., Green synthesis of silver nanoparticles through reduction with Solanum xanthocarpum L. berry extract: characterization, antimicrobial and urease inhibitory activities against Helicobacter pylori. International Journal of Molecular Sciences, 2012. 13(8): p. 9923-9941.

151. Banerjee, J. and R. Narendhirakannan, Biosynthesis of silver nanoparticles from Syzygium cumini (L.) seed extract and evaluation of their in vitro antioxidant activities. Dig J Nanomater Biostruct, 2011. 6(3): p. 961-968.

152. Padalia, H., P. Moteriya, and S. Chanda, Green synthesis of silver nanoparticles from marigold flower and its synergistic antimicrobial potential. Arabian Journal of Chemistry, 2015. 8(5): p. 732-741.

153. Rajaram, K., D. Aiswarya, and P. Sureshkumar, Green synthesis of silver nanoparticle using Tephrosia tinctoria and its antidiabetic activity. Materials Letters, 2015. 138: p. 251-254.

154. Ahmed, Q., et al., Antibacterial efficacy of silver nanoparticles synthesized employing Terminalia arjuna bark extract. Artificial cells, nanomedicine, and biotechnology, 2017. 45(6): p. 1192-1200.

155. Geethalakshmi, R. and D. Sarada, Synthesis of plant-mediated silver nanoparticles using Trianthema decandra extract and evaluation of their anti microbial activities. International Journal of Engineering Science and Technology, 2010. 2(5): p. 970-975. 
156. Deepak, P., et al., Structural characterization and evaluation of mosquito-larvicidal property of silver nanoparticles synthesized from the seaweed, Turbinaria ornata (Turner) J. Agardh 1848. Artificial cells, nanomedicine, and biotechnology, 2017. 45(5): p. 990-998.

157. Shafaghat, A., Synthesis and characterization of silver nanoparticles by phytosynthesis method and their biological activity. Synthesis and Reactivity in Inorganic, MetalOrganic, and Nano-Metal Chemistry, 2015. 45(3): p. 381-387.

158. Zargar, M., et al., Plant mediated green biosynthesis of silver nanoparticles using Vitex negundo L. extract. Journal of Industrial and Engineering Chemistry, 2014. 20(6): p. 4169-4175.

159. Singh, C., et al., A green biogenic approach for synthesis of gold and silver nanoparticles using Zingiber officinale. Digest Journal of Nanomaterials and Biostructures, 2011. 6(2): p. 535-542.

160. Gavade, N., et al., Biogenic synthesis of multi-applicative silver nanoparticles by using Ziziphus Jujuba leaf extract. Spectrochimica Acta Part A: Molecular and Biomolecular Spectroscopy, 2015. 136: p. 953-960.

161. Ju-Nam, Y. and J.R. Lead, Manufactured nanoparticles: an overview of their chemistry, interactions and potential environmental implications. Science of the total environment, 2008. 400(1-3): p. 396-414.

162. McConnell, W.P., et al., Electronic and optical properties of chemically modified metal nanoparticles and molecularly bridged nanoparticle arrays. 2000, ACS Publications.

163. Collier, C., et al., Reversible tuning of silver quantum dot monolayers through the metalinsulator transition. Science, 1997. 277(5334): p. 1978-1981.

164. Lu, A.H., E.e.L. Salabas, and F. Schüth, Magnetic nanoparticles: synthesis, protection, functionalization, and application. Angewandte Chemie International Edition, 2007. 46(8): p. 1222-1244.

165. Ghosh Chaudhuri, R. and S. Paria, Core/shell nanoparticles: classes, properties, synthesis mechanisms, characterization, and applications. Chemical reviews, 2011. 112(4): p. 2373-2433.

166. Monteiro, D.R., et al., The growing importance of materials that prevent microbial adhesion: antimicrobial effect of medical devices containing silver. International journal of antimicrobial agents, 2009. 34(2): p. 103-110.

167. Ahamed, M., M.S. AlSalhi, and M. Siddiqui, Silver nanoparticle applications and human health. Clinica chimica acta, 2010. 411(23-24): p. 1841-1848.

168. García-Barrasa, J., J. López-de-luzuriaga, and M. Monge, Silver nanoparticles on zinc oxide thin film: An insight in fabrication and characterization. Central European Journal of Chemistry, 2011. 64: p. 9-17.

169. Fabrega, J., et al., Silver nanoparticles: behaviour and effects in the aquatic environment. Environment international, 2011. 37(2): p. 517-531.

170. Dallas, P., V.K. Sharma, and R. Zboril, Silver polymeric nanocomposites as advanced antimicrobial agents: classification, synthetic paths, applications, and perspectives. Advances in colloid and interface science, 2011. 166(1-2): p. 119-135.

171. Gong, P., et al., Preparation and antibacterial activity of Fe3O4@ Ag nanoparticles. Nanotechnology, 2007. 18(28): p. 285604. 
172. Gong, H.M., et al., Illuminating dark plasmons of silver nanoantenna rings to enhance exciton-plasmon interactions. Advanced Functional Materials, 2009. 19(2): p. 298-303.

173. Krutyakov, Y.A., et al., Synthesis and properties of silver nanoparticles: advances and prospects. Russian Chemical Reviews, 2008. 77(3): p. 233.

174. Chen, X. and H.J. Schluesener, Nanosilver: a nanoproduct in medical application. Toxicology letters, 2008. 176(1): p. 1-12.

175. Li, Y. and S.-M. Chen, The electrochemical properties of acetaminophen on bare glassy carbon electrode. Int. J. Electrochem. Sci, 2012. 7(3): p. 2175-2187.

176. Noginov, M., et al., The effect of gain and absorption on surface plasmons in metal nanoparticles. Applied Physics B, 2007. 86(3): p. 455-460.

177. He, R., et al., Preparation of polychrome silver nanoparticles in different solvents. Journal of Materials Chemistry, 2002. 12(12): p. 3783-3786.

178. Tomaszewska, E., et al., Detection limits of DLS and UV-Vis spectroscopy in characterization of polydisperse nanoparticles colloids. Journal of Nanomaterials, 2013. 2013: p. 60.

179. Taleb, A., C. Petit, and M. Pileni, Optical properties of self-assembled $2 D$ and $3 D$ superlattices of silver nanoparticles. The Journal of Physical Chemistry B, 1998. 102(12): p. 2214-2220.

180. Link, S. and M.A. El-Sayed, Optical properties and ultrafast dynamics of metallic nanocrystals. Annual review of physical chemistry, 2003. 54(1): p. 331-366.

181. Karppinen, M., et al., Oxidation State of Cobalt in the $\mathrm{Na} x \mathrm{CoO} 2-\delta \odot$ y $\mathrm{H} 2 \mathrm{O}$ Superconductor. Chemistry of materials, 2004. 16(9): p. 1693-1696.

182. Ajitha, B., Y.A.K. Reddy, and P.S. Reddy, Biogenic nano-scale silver particles by Tephrosia purpurea leaf extract and their inborn antimicrobial activity. Spectrochimica Acta Part A: Molecular and Biomolecular Spectroscopy, 2014. 121: p. 164-172.

183. Sadeghi, B. and F. Gholamhoseinpoor, A study on the stability and green synthesis of silver nanoparticles using Ziziphora tenuior $(\mathrm{Zt})$ extract at room temperature. Spectrochimica Acta Part A: Molecular and Biomolecular Spectroscopy, 2015. 134: p. 310-315.

184. Shameli, K., et al., Green biosynthesis of silver nanoparticles using Callicarpa maingayi stem bark extraction. Molecules, 2012. 17(7): p. 8506-8517.

185. Buhr, E., et al., Characterization of nanoparticles by scanning electron microscopy in transmission mode. Measurement Science and Technology, 2009. 20(8): p. 084025.

186. Tai, L.-A., et al., Quantitative characterization of nanoparticles in blood by transmission electron microscopy with a window-type microchip nanopipet. Analytical chemistry, 2012. 84(15): p. 6312-6316.

187. Baraton, M.-I., Surface Analysis of Semiconducting Nanoparticles by FTIR Spectroscopy, in Nanocrystalline Metals and Oxides. 2002, Springer. p. 165-187.

188. Manjumeena, R., et al., Biogenic nanosilver incorporated reverse osmosis membrane for antibacterial and antifungal activities against selected pathogenic strains: an enhanced eco-friendly water disinfection approach. Journal of Environmental Science and Health, Part A, 2014. 49(10): p. 1125-1133. 
189. Saha, S., et al., Photochemical green synthesis of calcium-alginate-stabilized Ag and Au nanoparticles and their catalytic application to 4-nitrophenol reduction. Langmuir, 2009. 26(4): p. 2885-2893.

190. Sharma, K., et al., Silver nanoparticles: facile synthesis and their catalytic application for the degradation of dyes. RSC Advances, 2015. 5(33): p. 25781-25788.

191. Butun, S. and N. Sahiner, A versatile hydrogel template for metal nano particle preparation and their use in catalysis. Polymer, 2011. 52(21): p. 4834-4840.

192. Harish, S., et al., Role of $\mathrm{pH}$ in the synthesis of 3-aminopropyl trimethoxysilane stabilized colloidal gold/silver and their alloy sols and their application to catalysis. Materials Chemistry and Physics, 2011. 127(1-2): p. 203-207.

193. Cao, Y., et al., Engineering metal nanostructure for SERS application. Journal of Nanomaterials, 2013. 2013.

194. Botta, R., et al., Silver nanoclusters films for single molecule detection using Surface Enhanced Raman Scattering (SERS). Materials chemistry and Physics, 2013. 137(3): p. 699-703.

195. Zhu, S.-Q., et al., Gold nanoparticle thin films fabricated by electrophoretic deposition method for highly sensitive SERS application. Nanoscale research letters, 2012. 7(1): p. 613.

196. Rauwel, P., et al., Silver nanoparticles: Synthesis, properties, and applications. Advances in Materials Science and Engineering, 2015. 2015.

197. Zhang, T., et al., Synthesis of silver nanostructures by multistep methods. Sensors, 2014. 14(4): p. 5860-5889.

198. Fauss, E., The silver nanotechnology commercial inventory. University of Virginia, 2008.

199. Dong, X.-Y., et al., Nanosilver as a new generation of silver catalysts in organic transformations for efficient synthesis of fine chemicals. Catalysis Science \& Technology, 2015. 5(5): p. 2554-2574.

200. Chouhan, N., R. Ameta, and R.K. Meena, Biogenic silver nanoparticles from Trachyspermum ammi (Ajwain) seeds extract for catalytic reduction of p-nitrophenol to p-aminophenol in excess of NaBH4. Journal of Molecular Liquids, 2017. 230: p. 74-84.

201. A Bhosale, M. and B. M Bhanage, Silver nanoparticles: Synthesis, characterization and their application as a sustainable catalyst for organic transformations. Current Organic Chemistry, 2015. 19(8): p. 708-727.

202. Jayasree, L., P. Janakiram, and R. Madhavi, Characterization of Vibrio spp. associated with diseased shrimp from culture ponds of Andhra Pradesh (India). Journal of the world aquaculture society, 2006. 37(4): p. 523-532.

203. Oberdörster, E., Manufactured nanomaterials (fullerenes, C60) induce oxidative stress in the brain of juvenile largemouth bass. Environmental health perspectives, 2004. 112(10): p. 1058-1062.

204. Allsopp, M., A. Walters, and D. Santillo, Nanotechnologies and nanomaterials in electrical and electronic goods: A review of uses and health concerns. Greenpeace Research Laboratories, London, 2007.

205. Hussain, S., et al., In vitro toxicity of nanoparticles in BRL $3 A$ rat liver cells. Toxicology in vitro, 2005. 19(7): p. 975-983. 
206. Soto, K., L. Murr, and K. Garza, Cytotoxic responses and potential respiratory health effects of carbon and carbonaceous nanoparticulates in the Paso del Norte airshed environment. International journal of environmental research and public health, 2008. 5(1): p. 12-25.

207. Kone, B.C., M. Kaleta, and S.R. Gullans, Silver ion (Ag+)-induced increases in cell membrane $\mathrm{K}+$ and $\mathrm{Na}+$ permeability in the renal proximal tubule: reversal by thiol reagents. The Journal of membrane biology, 1988. 102(1): p. 11-19.

208. Shin, S.-H., et al., The effects of nano-silver on the proliferation and cytokine expression by peripheral blood mononuclear cells. International immunopharmacology, 2007. 7(13): p. 1813-1818.

209. McAuliffe, M.E. and M.J. Perry, Are nanoparticles potential male reproductive toxicants? A literature review. Nanotoxicology, 2007. 1(3): p. 204-210.

210. Burd, A., et al., A comparative study of the cytotoxicity of silver-based dressings in monolayer cell, tissue explant, and animal models. Wound repair and regeneration, 2007. 15(1): p. 94-104.

211. Kim, Y.S., et al., Subchronic oral toxicity of silver nanoparticles. Particle and fibre toxicology, 2010. 7(1): p. 20.

212. Kittler, S., et al., Toxicity of silver nanoparticles increases during storage because of slow dissolution under release of silver ions. Chemistry of Materials, 2010. 22(16): p. 4548-4554.

213. Gliga, A.R., et al., Size-dependent cytotoxicity of silver nanoparticles in human lung cells: the role of cellular uptake, agglomeration and Ag release. Particle and fibre toxicology, 2014. 11(1): p. 11.

214. Han, X., et al., Validation of an LDH assay for assessing nanoparticle toxicity. Toxicology, 2011. 287(1-3): p. 99-104.

215. Holder, A.L. and L.C. Marr, Toxicity of silver nanoparticles at the air-liquid interface. BioMed research international, 2012. 2013.

216. Stebounova, L.V., E. Guio, and V.H. Grassian, Silver nanoparticles in simulated biological media: a study of aggregation, sedimentation, and dissolution. Journal of Nanoparticle Research, 2011. 13(1): p. 233-244.

217. Carlson, C., et al., Unique cellular interaction of silver nanoparticles: size-dependent generation of reactive oxygen species. The journal of physical chemistry B, 2008. 112(43): p. 13608-13619.

218. Wang, X., et al., Use of coated silver nanoparticles to understand the relationship of particle dissolution and bioavailability to cell and lung toxicological potential. Small, 2014. 10(2): p. 385-398.

219. $\mathrm{Li}, \mathrm{N}$., T. Xia, and A.E. Nel, The role of oxidative stress in ambient particulate matterinduced lung diseases and its implications in the toxicity of engineered nanoparticles. Free Radical Biology and Medicine, 2008. 44(9): p. 1689-1699.

220. Kim, S. and D.Y. Ryu, Silver nanoparticle-induced oxidative stress, genotoxicity and apoptosis in cultured cells and animal tissues. Journal of Applied Toxicology, 2013. 33(2): p. 78-89.

221. Liu, J., et al., Chemical transformations of nanosilver in biological environments. ACS nano, 2012. 6(11): p. 9887-9899. 
222. Chwalibog, A., et al., Visualization of interaction between inorganic nanoparticles and bacteria or fungi. International Journal of Nanomedicine, 2010. 5: p. 1085.

223. Senjen, R., Nanosilver-a threat to soil, water and human health. Friends of the Earth Australia, 2007.

224. Wood, C.M., R.C. Playle, and C. Hogstrand, Physiology and modeling of mechanisms of silver uptake and toxicity in fish. Environmental Toxicology and Chemistry: An International Journal, 1999. 18(1): p. 71-83.

225. Asghari, S., et al., Toxicity of various silver nanoparticles compared to silver ions in Daphnia magna. Journal of nanobiotechnology, 2012. 10(1): p. 14.

226. Allahverdiyev, A.M., et al., Coping with antibiotic resistance: combining nanoparticles with antibiotics and other antimicrobial agents. Expert review of anti-infective therapy, 2011. 9(11): p. 1035-1052.

227. Singh, R., et al., Synthesis, optimization, and characterization of silver nanoparticles from Acinetobacter calcoaceticus and their enhanced antibacterial activity when combined with antibiotics. International journal of nanomedicine, 2013. 8: p. 4277.

228. Graves Jr, J.L., et al., Rapid evolution of silver nanoparticle resistance in Escherichia coli. Frontiers in genetics, 2015. 6: p. 42.

229. Manivasagan, P., et al., Biosynthesis, antimicrobial and cytotoxic effect of silver nanoparticles using a novel Nocardiopsis sp. MBRC-1. BioMed research international, 2013. 2013.

230. Kumar, P.S., et al., Extracellular biosynthesis of silver nanoparticle using Streptomyces sp. 09 PBT 005 and its antibacterial and cytotoxic properties. Applied Nanoscience, 2015. 5(2): p. 169-180.

231. Gurunathan, S., et al., Cytotoxicity of biologically synthesized silver nanoparticles in MDA-MB-231 human breast cancer cells. BioMed research international, 2013. 2013.

232. Namasivayam, S., P. Prakash, and G. Kumar, Anti tumor activity of biologically synthesized silver nanoparticles produced by Lactobacillus acidophilus against HEP 2. J Pharm Res, 2011. 4: p. 1651-1653.

233. You, J., Y. Zhang, and Z. Hu, Bacteria and bacteriophage inactivation by silver and zinc oxide nanoparticles. Colloids and Surfaces B: Biointerfaces, 2011. 85(2): p. 161-167.

234. Gülçin, I., Antioxidant activity of food constituents: an overview. Archives of toxicology, 2012. 86(3): p. 345-391.

235. Gülçin, İ., et al., Pomological features, nutritional quality, polyphenol content analysis, and antioxidant properties of domesticated and 3 wild ecotype forms of raspberries (Rubus idaeus L.). Journal of Food Science, 2011. 76(4): p. C585-C593.

236. Rice-Evans, C., N. Miller, and G. Paganga, Antioxidant properties of phenolic compounds. Trends in plant science, 1997. 2(4): p. 152-159. 